\title{
Survey of rodents and their ecto-parasites at some animal farms in Minia Governorate, Egypt
}

\author{
Ahmed Salah El Roby, Hassan Mohamed Hassan*, Hosafy Mohamed Eshbah , Arwa Abd Elhady \\ Abd Elhakeem \\ Plant Protection Department, Faculty of Agriculture, Minia University \\ *Corresponding author : dr_hassan200814@mu.edu.eg;Tel:+ 01141143055.
}

\section{Article information}

Received: 1 July 2021

Revised: 20 August 2021

Accepted: 21 August 2021

\section{Key words}

Survey

Rodents

Ectoparasites

Egypt.

\begin{abstract}
The main objective of this research is to recognize the rodent species prevailing under Minia region, Egypt conditions. The current study revealed the presence of three main species of rodents living in two animal farms (Salah El-Deen village and El-Minia district), El-Minia Governorate. These species of rodent were: Rattus rattus frugivorous; Rattus norvegicus and Mus musculus. The ectoparasites associated with these rodents were: two insects i.e., the louse, Polyplax spinulosa; the Flea, Pullex irritans as well as six mite species i.e., Ornithonyssus bacoti; Glycyphagus sp.; Myobia murismusculi; Dermanssus gallinae; Liponyssoides sanguineus and Cheyletiella parasitivorax. The mite species, O. bacoti; Glycyphagus sp. and C. parasitovorax were recorded on the bodies of $R$. r. frugivorous and $R$. norvegicus, but these species of mites were recorded from the body of the house mouse, M. musculus. The two mite species $M$. murismusculi and D. gallinae were recorded in association with the three surveyed rodent species. The fleas were more common with $R$. $r$. frugivorous and $M$. musculus, but completely disappeared with $R$. norvegicus. The louse, $P$. spinulosa was recorded on $R$. $r$. frugivorous and $M$. musculus and completely missed on $R$. norvegicus. In Shosha animal farm (Samalote district), only two rodent species were recorded ( $R$. r. frugivorus and $R$. norvegicus), and the mite species accompanied with both rodent species were $O$. bacoti; Glycyphagus sp.; $M$. murismusculi and C. parasitivorax. While the lice, $P$. spinulosa were found only on the body of $R$. r. frugivorous and completely disappeared on $R$. norvegicus.
\end{abstract}

\section{Introduction}

Rodents are cosmopolitan in their distribution and they constitute the largest group of mammals represented about 40 $\%$ of all mammals in the world [1] and [2] surveyed 51 species of rodent in Egypt belonged to the suborder Myomorpha; eleven species fall under the family Muridae the species pertaining to these genera: (Arvicanthis, Rattus, Acomys, Mus and Nesoke) are domestic and commensal animals found of abundance, while five families presented are low abundance living in desert and semi desert. Some researchers in Upper Egypt studied on the dominant rate species (i.e., $R$. norvegicus; $R$. rattus; A. cahirinus; A. niloticus; M. musculus; Geribilus sp. and Juculus sp.). These dominant species and their densities are related to their habitats, crop installation, nearly reclamation land and abundance shelter and food and seasons $[3,4,5,6,7,8,9]$

In tropical and subtropical countries, at least 20 species of rodents have been recognized as pests of agricultural crops, including $R$. norvegicus and $R$. rattus [10]. Rats cause destruction of foodstuff, electrical equipment and buildings by gnawing or contamination with excreta resulting in significant economic losses [11]. Rats can carry a range of bacteria and viruses which lead to the spread of diseases such as plague, arena and Hanta virus, rat typhus and helminthasis as hymenolepiasis, schistosomiasis and lung worm[12]. Screening of rodent's ectoparasites was carried out by [13] to assess their potential as reservoirs of zoonoses [14].

In Egypt, rodent's problem increased in the last two decades. The main reasons are due mainly to the diversion in agricultural ecosystem, land reclamation and construction of new cities in the desert areas. The wide usage of pesticides for controlling agricultural pests lead to rodent natural enemies reduction such as some reptiles and wild birds. Ectoparasites associated with rodents in Egypt were surveyed and the most abundance ectoparasites were different species of mites especially: $O$. bacoti, Laelaps nuttalli, D. gallinae, Allodermanyssus sanguincus, Eulaelaps stabularis and Radfordia ensiifera. In the other hand, fleas and lice were also detected [15-19]. This study aims to survey the rodents and their associated ectoparasites in two animal farms in El-Minia Governorate.

\section{2-Materials and Methods}

\subsection{Survey of rodents in some animal farms in El-Minia Governorate:}

Twenty wire-box traps were baited and distributed twice every week at $6 \mathrm{pm}$ and collected at 7 am in the surveyed areas. The captured rodents were classified morphologically and counted.

2.2 Studies on the population density of ectoparasites associated with rodent species in the tested animal farms in El-Minia Governorate: 
Rodents were collected alive and classified to species and subspecies, male and female of each as well as the distribution frequency of each species (\%). For collecting the rodent ectoparasites, the captured rodent bodies will be dipped in bowl filled partially with liquid soap solution (water with few drops of detergent) to kill rodents by asphyxia and to remove the ectoparasites attached to the rodent bodies, then these ectoparasites were delivered to small jar contained $75 \%$ ethyl alcohol for identification by to aid of the stereoscopic microscope. The ectoparasites were classified as fleas, lice and mites.

Identification of the ectoparasites was done by using different keys constructed by [20-24]. One rodent represented one replicate. The average numbers of the detected animal organisms of four replicates recorded and general mean was estimated and recorded.

\section{3-Results and Discussion}

\subsection{Rodents and their associated ectoparasites in animal farms of Salah El-Deen village, El-Minia district of El- Minia Governorate:}

The surveyed rodents at animal farms in Salah El-Deen village and El-Minia district were tested during 2017 and 2018 for detecting their associated ectoparasites (Table 1). The surveyed rodents were: ( $R . \quad r$. frugivorous, $R$. norvegicus and $M$. musculus), and their associated ectoparasites were the louse, $P$. spinulosa; the flea, $P$. irritans and different mites species $(O$. bacoti, Glycyphagus sp., M. murismusculi, D. gallinae, L. sanguineus and $C$. parasitovorax).

Data in Table (1), show that both $O$. bacoti and Glycyphagus sp. were detected with $R$. $r$. frugivorous and $R$. norvegicus and completely disappeared on $M$. musculus also, $C$. parasitivorax mite was detected on $R$. r. frugivorous and $R$. norvegicus but missed on M. musculus. While M. murismusculi and D. gallinae were recorded on all surveyed rodents. Flea was recorded with $R$. r. frugivorous and M. musculus and completely disappeared on $R$. norvegicus. The louse, $P$. spinulosa was attached on $R . r$. frugivorous and M. musculus, but not observed on $R$. norvegicus. The lice were disappeared on $R$. norvegicus that may be attributed to the contamination of Norwegian rat bodies by ammonia resulting from their continuous visiting the closets. [25] found that ammonia may be kill lice.

Table (1): Survey of rodent ectoparasites in farm animals in both farms of El-Minia Governorate, during, 2017 and 2018

\begin{tabular}{clll}
\hline $\begin{array}{c}\text { Rodents/ } \\
\text { Ectoparasite } \\
\text { s }\end{array}$ & R. r. frugivorus & R. norvegicus & M. musculus \\
\hline Lice & $\begin{array}{l}\text { Polyplax } \\
\text { spinulosa }\end{array}$ & - & \\
\hline Fleas & Pullex irritans & - & $\begin{array}{l}\text { Polyplax } \\
\text { spinulosa }\end{array}$ \\
& $\begin{array}{l}\text { Ornithonyssus } \\
\text { bacoti }\end{array}$ & Ornithonyssus & Pullex irritans \\
& Glycyphagus sp. & Glycyphagus sp. & - \\
Mites & Myobia & Myobia & Myobia \\
& murismusculi & murismusculi & murismusculi \\
& Dermanssus & Dermanssus & Dermanssus \\
gallinae & gallinae & gallinae \\
& - & - & $\begin{array}{l}\text { Liponyssoides } \\
\text { sanguineus }\end{array}$ \\
& cheyletiella & Cheyletiella & - \\
& parasitivorax & parasitivorax & \\
\hline
\end{tabular}

Data in Tables (2, 3 \& 4), explain the monthly and seasonal abundance of some ectoparasites collected from the body surface of $R$. r. frugivorus, $R$.norvegicus and M. musculus in three animal farms (Salah El-Deen village, El-Minia district, ElMinia city, during, 2017 and 2018. Total numbers of lice on $R$. $r$. frugivorus in 2017 and 2018 were 30 and 20/rat. While these numbers were on M. musculus 11 and 7/mouse. (Table 4), this difference may be due to the increase in hair length on the Norwegian rats compared to the house mouse in agreement with [26]. Total number of fleas on R. r. frugivorous in 2017 and 2018 were 24 and $21 /$ rat, and 42 and 37/mouse on $M$. musculus. This difference may be due to the visiting of $M$. musculus to the human building. D. gallinae surpassed other mites with the tested rats recording 225, 317 and 49/rat in 2017 and 178, 200 and 29 in 2018 on $R$. r. frugivorus, $R$. norvegicus and M. musculus, respectively (Tables 2,3 \& 4). This result explained that on $R$. norvegicus the highest number of the $D$. gallinae recorded perhaps it is due to the fact that the Norwegian rat used to live inside poultry farms. The $C$. parasitivorax was completely disappeared on $M$. musculus. Conversely, for both rodent species recorded 65, 78, 43 and 48/rat in 2017 and 2018, consecutively. This is due mainly to the frequently presence of $C$. parasitovorax with rabbits, as well as for the Norwegian rat, which used to attach rabbits and feed on their bodies.

Table (2) and Figure (1), represented the percentage of ectoparasites associated with $R$. $r$. frugivorous overall the year. The high percentage overall the year was 24.75 with $D$. gallinae in 2017 while the lowest one was $2.31 \%$ for P. irritans in 2018. Table (3) and Figure (2) represent the percentage of ectoparasites associated with $R$. norevegicus overall the year. The highest percentage was $33.51 \%$ for D. gallinae in 2017, while the lowest one was $4.2 \%$ M. murismusculi in 2018.

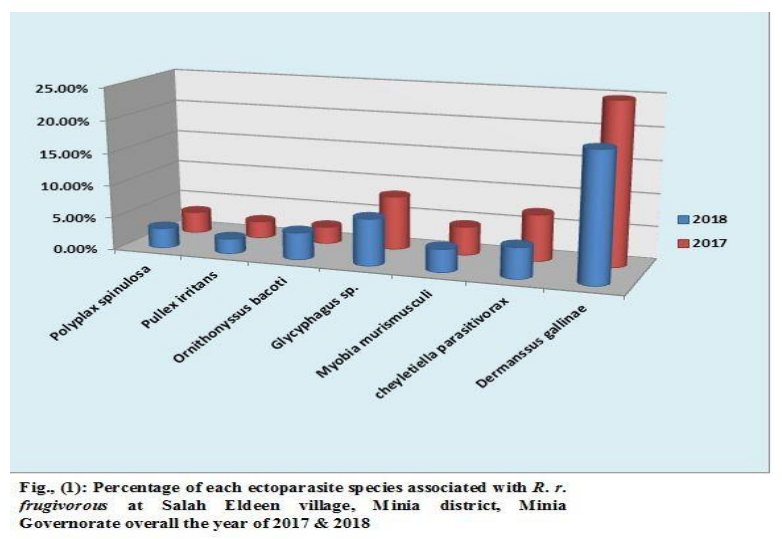
frugivorous at Salah Fldeen village, Minia district, Minia
Governorate overall the year of $2017 \& 2018$

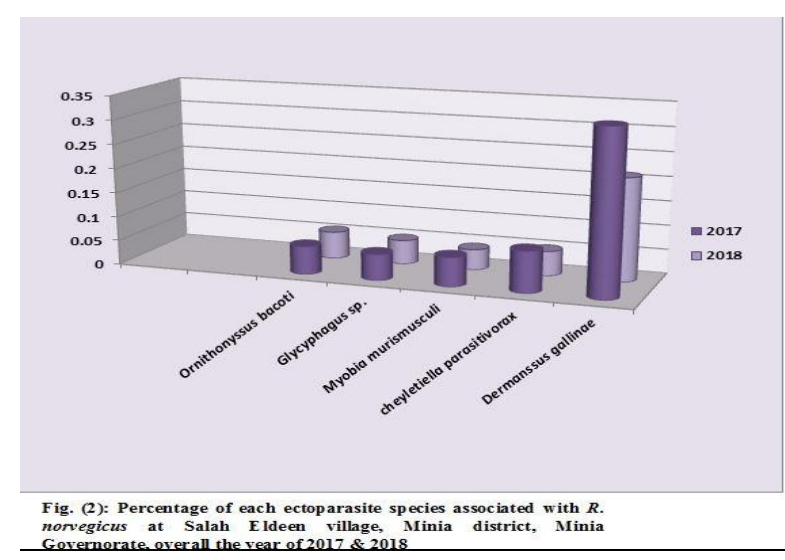


Table (2): Monthly abundance of some ectoparasites (No./rat) collected from the body surface of R. r. frugivorus in both farms in ElMinia governorate during, 2017 and 2018

\begin{tabular}{|c|c|c|c|c|c|c|c|c|c|c|c|c|c|c|}
\hline Species & spin & $\begin{array}{l}P . \\
\text { ulosa }\end{array}$ & P. ir & itans & 7. $b$ & acoti & $\begin{array}{r}\text { Glyc } \\
\text { gus }\end{array}$ & $\begin{array}{l}\text { ypha } \\
\text { sp. }\end{array}$ & muri & $\begin{array}{l}\text { 1. } \\
\text { smusc } \\
\text { li }\end{array}$ & D. gal & linae & $\begin{array}{r} \\
\text { gara } \\
r \\
\end{array}$ & $\begin{array}{l}\text { itivo } \\
x\end{array}$ \\
\hline Year & 201 & 2018 & 201 & 2018 & 20 & 201 & 201 & 201 & 201 & 2018 & 2017 & 201 & 201 & 201 \\
\hline & 7 & & 7 & & 17 & 8 & 7 & 8 & 7 & & & 8 & 7 & 8 \\
\hline Jan. & 2 & 1 & 1 & 1 & 1 & 0 & 2 & 1 & 0 & 1 & 4 & 3 & 2 & 0 \\
\hline Feb. & 0 & 1 & 2 & 0 & 2 & 3 & 5 & 4 & 3 & 2 & 10 & 9 & 0 & 1 \\
\hline March & 3 & 2 & 1 & 0 & 2 & 3 & 6 & 5 & 2 & 3 & 5 & 7 & 0 & 2 \\
\hline April & 4 & 2 & 3 & 2 & 3 & 4 & 7 & 6 & 5 & 4 & 20 & 15 & 6 & 4 \\
\hline May & 3 & 1 & 2 & 3 & 5 & 3 & 10 & 8 & 10 & 6 & 33 & 29 & 8 & 5 \\
\hline June & 2 & 3 & 4 & 3 & 6 & 5 & 13 & 10 & 6 & 4 & 35 & 24 & 9 & 6 \\
\hline July & 3 & 2 & 3 & 2 & 5 & 6 & 6 & 7 & 5 & 3 & 30 & 25 & 10 & 5 \\
\hline Aug. & 4 & 5 & 4 & 3 & 7 & 6 & 8 & 7 & 4 & 3 & 37 & 30 & 12 & 9 \\
\hline Sept. & 2 & 5 & 1 & 2 & 5 & 4 & 2 & 4 & 0 & 2 & 25 & 20 & 7 & 5 \\
\hline Oct. & 4 & 6 & 2 & 4 & 5 & 3 & 6 & 6 & 2 & 1 & 15 & 10 & 5 & 4 \\
\hline Nov. & 1 & 0 & 1 & 0 & 2 & 1 & 6 & 4 & 2 & 3 & 5 & 4 & 4 & 2 \\
\hline Dec. & 2 & 0 & 0 & 1 & 2 & 0 & 4 & 3 & 1 & 0 & 6 & 2 & 2 & 0 \\
\hline Total & 30 & 28 & 24 & 21 & 45 & 38 & 75 & 65 & 40 & 32 & 225 & 178 & 65 & 43 \\
\hline$\%$ of & 3.3 & 3.08 & 2.64 & 2.31 & 2.6 & 7.18 & 3.25 & 7.15 & 4.40 & 3.52 & 24.75 & 19.5 & 7.15 & 4.73 \\
\hline $\begin{array}{l}\text { each } \\
\text { species } \\
\text { overall } \\
\text { the yea }\end{array}$ & $\begin{array}{l}j \% \\
s \\
1 \\
a\end{array}$ & $\%$ & $\%$ & $\%$ & $1 \%$ & $\%$ & $\%$ & $\%$ & $\%$ & $\%$ & $\%$ & $8 \%$ & $\%$ & $\%$ \\
\hline
\end{tabular}

\subsection{Rodents and their associated ectoparasites in} Shosha farm (Samalote), El-Minia Governorate during 2017 and 2018:

Table (5) Surveyed and the three rodent species and their associated ectoparasites in Shosha farm in Samalote district, during 2017 and 2018. Two rodent species were detected in Shosha animal farms ( $R$. r. frugivorus and R. norvegicus). The detected ectoparasites accompanyed with $R$. $r$. frugivorus were: the lice, $P$. spinulosa and four mite species (i.e., O. bacoti; Glycyphagus sp.; $M$. murismusculi and $C$. parasitovorax). These mites were recorded also with $R$. norvigicus while $P$. spinulosa was completely disappeared on the body of $R$. norvigicus.

Table (3): Monthly abundance of some ectoparasites collected from the body surface of Rattus norvegicus in both farms of El-Minia Governorate during, 2017 and 2018

\begin{tabular}{|c|c|c|c|c|c|c|c|c|c|c|}
\hline \multirow[t]{2}{*}{$\begin{array}{l}\text { Species } \\
\text { Year }\end{array}$} & \multicolumn{2}{|c|}{ O. bacoti } & \multicolumn{2}{|c|}{$\begin{array}{c}\text { Glycyphag } \\
\text { us sp. }\end{array}$} & \multicolumn{2}{|c|}{$\begin{array}{c}M . \\
\text { murismusc } \\
\text { uli } \\
\end{array}$} & \multicolumn{2}{|c|}{ D. gallinae } & \multicolumn{2}{|c|}{$\begin{array}{c}C . \\
\text { parasitivor } \\
a x\end{array}$} \\
\hline & 2017 & $\begin{array}{l}21 \\
08\end{array}$ & $\begin{array}{c}201 \\
7\end{array}$ & $\begin{array}{l}21 \\
08\end{array}$ & $\begin{array}{c}201 \\
7\end{array}$ & $\begin{array}{l}21 \\
08\end{array}$ & $\begin{array}{c}201 \\
7\end{array}$ & $\begin{array}{l}21 \\
08\end{array}$ & $\begin{array}{c}201 \\
7\end{array}$ & $\begin{array}{l}21 \\
08\end{array}$ \\
\hline Jan. & 2 & 0 & 1 & 0 & 2 & 1 & 10 & 8 & 2 & 0 \\
\hline Feb. & 1 & 2 & 1 & 2 & 4 & 2 & 11 & 5 & 3 & 1 \\
\hline March & 2 & 3 & 3 & 2 & 3 & 4 & 15 & 7 & 4 & 2 \\
\hline April & 4 & 5 & 5 & 3 & 6 & 5 & 22 & 10 & 2 & 2 \\
\hline May & 5 & 4 & 8 & 7 & 11 & 9 & 30 & 15 & 8 & 5 \\
\hline June & 5 & 6 & 9 & 10 & 5 & 4 & 40 & 30 & 10 & 7 \\
\hline July & 7 & 8 & 7 & 5 & 7 & 5 & 45 & 35 & 15 & 11 \\
\hline Aug. & 8 & 6 & 5 & 6 & 6 & 3 & 38 & 28 & 12 & 9 \\
\hline Sept. & 6 & 7 & 3 & 2 & 5 & 4 & 35 & 24 & 9 & 6 \\
\hline Oct. & 7 & 5 & 4 & 5 & 3 & 2 & 36 & 22 & 6 & 3 \\
\hline Nov. & 5 & 4 & 3 & 4 & 3 & 1 & 20 & 9 & 4 & 2 \\
\hline Dec. & 3 & 3 & 2 & 1 & 2 & 0 & 15 & 7 & 3 & 0 \\
\hline Total & 55 & 53 & 51 & 47 & 57 & 40 & 317 & $\begin{array}{c}20 \\
0\end{array}$ & 78 & 48 \\
\hline $\begin{array}{c}\% \text { of } \\
\text { each } \\
\text { species } \\
\text { overall } \\
\text { the } \\
\text { year }\end{array}$ & $5.81 \%$ & $\begin{array}{l}5.6 \\
0 \\
\%\end{array}$ & $\begin{array}{c}5.39 \\
\%\end{array}$ & $\begin{array}{l}4.9 \\
7 \\
\%\end{array}$ & $\begin{array}{c}6.02 \\
\%\end{array}$ & $\begin{array}{c}4.2 \\
3 \\
\%\end{array}$ & $\begin{array}{l}33 . \\
51 \\
\%\end{array}$ & $\begin{array}{l}21 . \\
14 \\
\%\end{array}$ & $\begin{array}{c}8.52 \\
\%\end{array}$ & $\begin{array}{l}5 . \\
07 \\
\%\end{array}$ \\
\hline
\end{tabular}

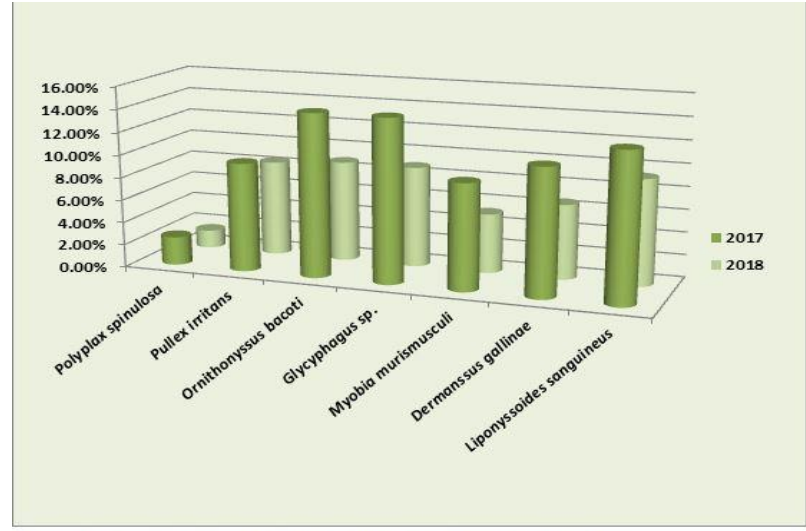

Fig. (3): Percentage of each ectoparasite species associated with $M$. Eld een village, Minia district, M inia Governorate, over all the year of $2017 \& 2018$

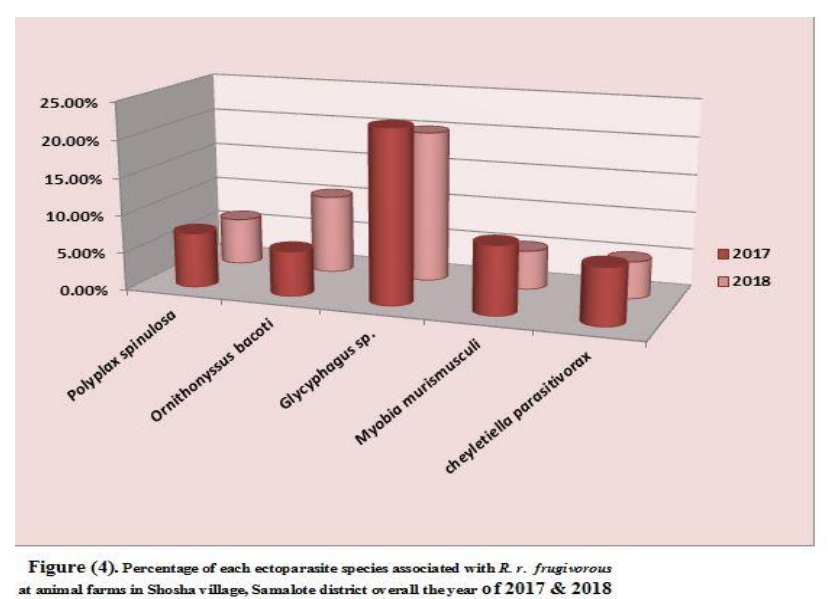

Table (4): Monthly abundance of some ectoparasites collected from the body surface of M. musculus in farm animals in both farms of ElMinia Governorate, during, 2017 and 2018

\begin{tabular}{|c|c|c|c|c|c|c|c|c|c|c|c|c|}
\hline \multirow{2}{*}{$\begin{array}{l}\begin{array}{c}\text { fSpe } \\
\text { cies }\end{array} \\
\text { Yea }\end{array}$} & \multicolumn{2}{|c|}{$\begin{array}{c}P . \\
\text { spinulosa }\end{array}$} & \multicolumn{2}{|c|}{$\begin{array}{c}P . \\
\text { irritans }\end{array}$} & \multicolumn{2}{|c|}{$\begin{array}{l}\text { Glycypha } \\
\text { gus sp. }\end{array}$} & \multicolumn{2}{|c|}{$\begin{array}{c}\text { M.murism } \\
\text { usculi }\end{array}$} & \multicolumn{2}{|c|}{$\begin{array}{c}D . \\
\text { gallinae }\end{array}$} & \multicolumn{2}{|c|}{$\begin{array}{c}L . \\
\text { sanguin } \\
\text { eus }\end{array}$} \\
\hline & 20 & 20 & 20 & 20 & 20 & 20 & 20 & 20 & 20 & 20 & 20 & 2 \\
\hline $\mathrm{r}$ & 17 & 18 & 17 & 18 & 17 & 18 & 17 & 18 & 17 & 18 & 17 & $\begin{array}{l}0 \\
1 \\
8\end{array}$ \\
\hline Jan. & 0 & 0 & 2 & 1 & 0 & 0 & 0 & 1 & 0 & 0 & 1 & 0 \\
\hline Feb. & 0 & 0 & 0 & 2 & 5 & 3 & 0 & 0 & 0 & 0 & 3 & 2 \\
\hline $\begin{array}{l}\text { Mar } \\
\text { ch }\end{array}$ & 0 & 1 & 0 & 2 & 4 & 2 & 0 & 0 & 0 & 0 & 4 & 5 \\
\hline $\begin{array}{c}\text { Apri } \\
1\end{array}$ & 1 & 0 & 4 & 3 & 6 & 5 & 4 & 2 & 5 & 3 & 6 & 4 \\
\hline May & 1 & 0 & 5 & 4 & 9 & 7 & 6 & 3 & 5 & 4 & 7 & 6 \\
\hline June & 2 & 2 & 4 & 5 & 10 & 6 & 5 & 4 & 7 & 5 & 5 & 4 \\
\hline July & 2 & 1 & 5 & 4 & 5 & 3 & 5 & 2 & 10 & 6 & 6 & 4 \\
\hline Aug & 1 & 1 & 7 & 5 & 7 & 4 & 6 & 3 & 8 & 5 & 6 & 5 \\
\hline Sept & 2 & 2 & 6 & 4 & 3 & 2 & 7 & 4 & 6 & 3 & 7 & 5 \\
\hline Oct. & 2 & 0 & 4 & 3 & 7 & 5 & 5 & 3 & 4 & 2 & 6 & 4 \\
\hline Nov & 0 & 0 & 3 & 3 & 5 & 2 & 2 & 1 & 3 & 1 & 3 & 2 \\
\hline Dec & 0 & 0 & 2 & 1 & 2 & 0 & 1 & 0 & 1 & 0 & 3 & 0 \\
\hline $\begin{array}{c}\text { Tota } \\
1\end{array}$ & 11 & 7 & 42 & 37 & 63 & 39 & 41 & 23 & 49 & 29 & 57 & $\begin{array}{l}4 \\
1\end{array}$ \\
\hline$\%$ & 2.5 & 1.5 & 9.5 & 8. & 14. & 8.8 & 9.3 & 5.2 & 11. & 6.6 & 12 & 9. \\
\hline of & 0 & 9 & $7 \%$ & 43 & 35 & 8 & 3 & 4 & 16 & 0 & .9 & 3 \\
\hline each & $\%$ & $\%$ & & $\%$ & $\%$ & $\%$ & $\%$ & $\%$ & $\%$ & $\%$ & 8 & 3 \\
\hline spec & & & & & & & & & & & $\%$ & \\
\hline ies & & & & & & & & & & & & \\
\hline over & & & & & & & & & & & & \\
\hline all & & & & & & & & & & & & \\
\hline $\begin{array}{l}\text { the } \\
\text { year }\end{array}$ & & & & & & & & & & & & \\
\hline
\end{tabular}


Table (5): Survey of rodent ectoparasites in Shosha farm (Samalote), El-Minia Governorate during, 2017 and 2018

\begin{tabular}{lll}
\hline $\begin{array}{l}\text { Rodents/ } \\
\text { Ectoparasites }\end{array}$ & R. r. frugivorus & R. norvegicus \\
\hline Lice & Polyplax spinulosa & - \\
\multirow{4}{*}{ Mites } & Ornithonyssus bacoti & Ornithonyssus bacoti \\
& $\begin{array}{l}\text { Glycyphagus sp. } \\
\text { Myobia murismusculi }\end{array}$ & $\begin{array}{l}\text { Glycyphagus } \text { sp. } \\
\text { Myobia murismusculi }\end{array}$ \\
& $\begin{array}{l}\text { Cheyletiella } \\
\text { parasitivorax }\end{array}$ & Cheyletiella parasitivorax \\
\hline
\end{tabular}

Data in Table (6) explained the monthly abundance of some ectoparasites collected from the body surface of $R$. $r$. frugivorus in Shosha farm in Samalote district during 2017 and 2018. The total number of $P$. spinulosa was 28 and 24/rat during 2017 and 2018. As for the mite, $O$. bacoti the recorded number was 40 and 23/rat in 2017 and 2018. C. parasitovorax recorded 29 and 19 /rat in 2017 and 2018. M. murismusculi recorded 35 and 20/rat in 2017 and 2018. The highest number detected was 88 and77/rat in 2017 and 2018 with Glycyphagus sp.Table (6) and Figure (4), represented the percentage of associated ectoparasites on $R$. $r$. frugivorous overall the year. The highest percentage was 22.98 with Glycephagus sp. in 2017, while the lowest percentage was $4.96 \%$ that recorded with $C$. parasitovorax in 2018 .

Data in Table (7) explained the monthly abundance of ectoparasites collected from the body surface of. $R$. norvegicus in Shosha farm in Samalote district during 2017 and 2018. The louse, $P$. spinulosa was completely disappeared on the Norwegian rat as for the mite species, O. bacoti recorded 32 and 17 individuels. M. murismusculi 55 and 47 individuels and Glycyphagus sp. recorded 47 and 42 individuals on $R$. norvegicus the highest number of ectoparasites on $R$. norvegicus was 81 and 79/rat with $C$. parasitivorax in 2017 and 2018. Table (7) and Figure (5), represented the percentage of ectoparasite species associated on $R$. norevegicus overall the year. The highest percentage was 20.25 with $C$. parasitivorax in 2017, while the lowest one was $4.25 \%$ recorded with $O$. bacoti in 2018 .

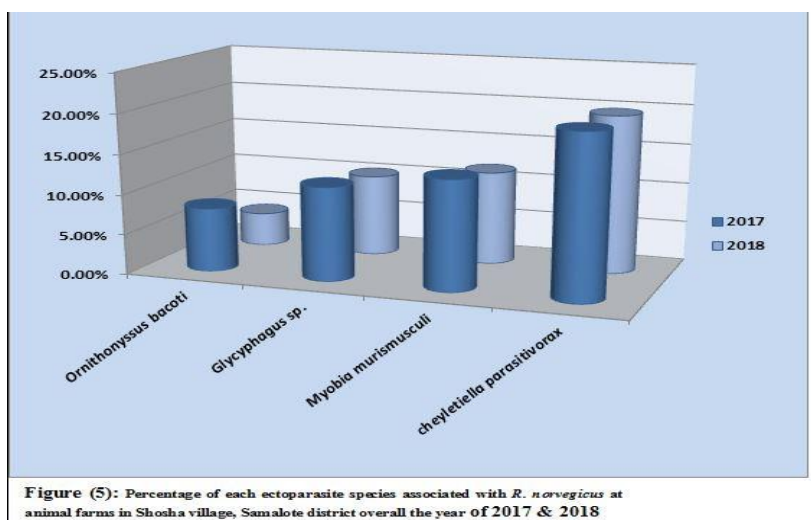

\section{4- Conclusion}

For recognizing the problems caused by rodents and their associated ectoparasites the surveying of these pests become imperative. This research aimed to survey rodents and their ectoparasites in some animal production farms located in Minia region. The current study showed the presence of three rodent species that used to feed inside animal production farms (i.e., $R$. $r$. frugivorous; $R$. norevegicus and M. musculus). It was also possible to identify several species of ectoparasites on the bodies of these three rodent species which are: single species of lice $(P$. spinulosa); one species of flea $(P$. irritanus) and six species of mites (i.e., $O$. bacoli; Glycyphagus sp.; $M$. murismusculi; D. gallinae; L. sanguineus and C. parasitovorax) these results are in agreement with those obtained by $[3,6,7,16,17,18,9]$

Table (6): Monthly abundance of some ectoparasites collected from the body surface of R. r. frugivorus in Shosha farm (Samalote), during, 2017 and 2018

\begin{tabular}{|c|c|c|c|c|c|c|c|c|c|c|}
\hline Species & \multicolumn{2}{|c|}{$\begin{array}{c}P . \\
\text { spinulosa }\end{array}$} & \multicolumn{2}{|c|}{ O. bacoti } & \multicolumn{2}{|c|}{$\begin{array}{c}\text { Glycyphagu } \\
s \text { sp. }\end{array}$} & \multicolumn{2}{|c|}{$\begin{array}{c}M . \\
\text { murismuscu } \\
\text { li }\end{array}$} & \multicolumn{2}{|c|}{$\begin{array}{c}C . \\
\text { parasitivorax }\end{array}$} \\
\hline Year & $\begin{array}{c}201 \\
7\end{array}$ & $\begin{array}{l}20 \\
18\end{array}$ & 2018 & $\begin{array}{c}201 \\
7\end{array}$ & 201 & $\begin{array}{l}20 \\
18\end{array}$ & $\begin{array}{c}201 \\
7\end{array}$ & $\begin{array}{l}20 \\
18\end{array}$ & $\begin{array}{c}201 \\
7\end{array}$ & 2018 \\
\hline Jan. & 2 & 1 & 1 & 0 & 4 & 3 & 0 & 0 & 0 & 0 \\
\hline Feb. & 1 & 0 & 2 & 0 & 6 & 5 & 2 & 0 & 1 & 0 \\
\hline March & 1 & 0 & 2 & 0 & 5 & 3 & 2 & 1 & 1 & 0 \\
\hline April & 3 & 2 & 4 & 3 & 8 & 7 & 4 & 2 & 2 & 2 \\
\hline May & 0 & 1 & 3 & 4 & 12 & 10 & 5 & 3 & 3 & 2 \\
\hline June & 3 & 2 & 5 & 4 & 15 & 13 & 6 & 3 & 5 & 3 \\
\hline July & 2 & 3 & 6 & 3 & 9 & 8 & 4 & 2 & 4 & 2 \\
\hline Aug. & 4 & 5 & 5 & 4 & 10 & 8 & 5 & 4 & 5 & 4 \\
\hline Sept. & 3 & 4 & 6 & 4 & 14 & 9 & 2 & 2 & 3 & 3 \\
\hline Oct. & 6 & 5 & 2 & 3 & 10 & 6 & 1 & 2 & 2 & 2 \\
\hline Nov. & 2 & 1 & 3 & 2 & 5 & 3 & 2 & 1 & 3 & 1 \\
\hline Dec. & 1 & 0 & 1 & 0 & 4 & 2 & 2 & 0 & 0 & 0 \\
\hline Total & 28 & 24 & 40 & 23 & 88 & 77 & 35 & 20 & 29 & 19 \\
\hline $\begin{array}{l}\% \text { of } \\
\text { each } \\
\text { species } \\
\text { overall } \\
\text { the year }\end{array}$ & $\begin{array}{c}7.31 \\
\%\end{array}$ & $\begin{array}{l}6.2 \\
7 \%\end{array}$ & $\begin{array}{c}10.44 \\
\%\end{array}$ & $\begin{array}{l}6.0 \\
0 \%\end{array}$ & $\begin{array}{l}22 . \\
98 \\
\%\end{array}$ & $\begin{array}{l}20 . \\
10 \\
\%\end{array}$ & $\begin{array}{c}9.14 \\
\%\end{array}$ & $\begin{array}{l}5.2 \\
2 \%\end{array}$ & $\begin{array}{l}7.5 \\
7 \%\end{array}$ & $4.96 \%$ \\
\hline
\end{tabular}

Table (7): Monthly and seasonal abundance of some ectoparasites collected from the body surface of R. norvegicus in Shosha farm (Samalote), El-Minia Governorate during, 2017 and 2018

\begin{tabular}{|c|c|c|c|c|c|c|c|c|}
\hline \multirow[t]{2}{*}{$\begin{array}{l}\text { Species } \\
\text { Year }\end{array}$} & \multicolumn{2}{|c|}{ O. bacoti } & \multicolumn{2}{|c|}{$\begin{array}{c}\text { Glycyphagus } \\
\text { sp. }\end{array}$} & \multicolumn{2}{|c|}{$\begin{array}{c}M . \\
\text { murismuscul } \\
i \\
\end{array}$} & \multicolumn{2}{|c|}{ C. parasitivorax } \\
\hline & 2017 & $\begin{array}{c}201 \\
8\end{array}$ & 2017 & $\begin{array}{c}201 \\
8\end{array}$ & $\begin{array}{c}201 \\
7\end{array}$ & $\begin{array}{c}201 \\
8\end{array}$ & $\begin{array}{c}201 \\
7\end{array}$ & 2018 \\
\hline Jan. & 0 & 0 & 1 & 0 & 2 & 1 & 2 & 2 \\
\hline Feb. & 1 & 0 & 2 & 1 & 2 & 2 & 3 & 4 \\
\hline March & 2 & 0 & 1 & 2 & 4 & 3 & 3 & 3 \\
\hline April & 4 & 2 & 4 & 2 & 6 & 7 & 5 & 6 \\
\hline May & 4 & 3 & 8 & 6 & 7 & 5 & 9 & 7 \\
\hline June & 5 & 3 & 6 & 5 & 5 & 5 & 10 & 8 \\
\hline July & 3 & 2 & 8 & 6 & 3 & 4 & 12 & 11 \\
\hline Aug. & 4 & 2 & 7 & 5 & 5 & 6 & 9 & 9 \\
\hline Sept. & 5 & 3 & 5 & 6 & 6 & 4 & 10 & 8 \\
\hline Oct. & 2 & 1 & 3 & 4 & 7 & 5 & 8 & 10 \\
\hline Nov. & 2 & 1 & 2 & 3 & 5 & 3 & 6 & 7 \\
\hline Dec. & 0 & 0 & 0 & 2 & 3 & 2 & 4 & 4 \\
\hline Total & 32 & 17 & 47 & 42 & 55 & 47 & 81 & 79 \\
\hline $\begin{array}{l}\% \text { of each } \\
\text { species } \\
\text { overall } \\
\text { the year }\end{array}$ & $\begin{array}{c}8.00 \\
\%\end{array}$ & $\begin{array}{c}4.25 \\
\%\end{array}$ & $\begin{array}{c}11.75 \\
\%\end{array}$ & 10. & $\begin{array}{c}13.7 \\
5 \%\end{array}$ & 11.' & $\begin{array}{c}20.2 \\
5 \%\end{array}$ & $19.75 \%$ \\
\hline
\end{tabular}




\section{REFRENCES}

[1]Bajomi, D. (1984): Commensal rodent problems in Hungry Organization and practice of vertebrate pest control Hampshire. Conference England, 18-20.

[2]Hoogstral, H. (1963): A brief review of contemporary land mammals of Egypt (including Sinai). 2: lagomorpha and Rodentia. Journal Egyptian Publication Hlth., Assoc., 38: 1-34.

[3]Salit, A.M.; Helal, T.Y.; Ali, M.A.; Abdel-Gawad, K.H. and Arafa, M.S. (1982): Composition of the rodent species in newly reclaimed semi-desert area comparing with cultivated land. Assiut Journal of Agricultural Sciences, 13(2): 53-62.

[4]Abazaid, A.A. (1990): Efficiency of some common used rodenticide and some new alternatives against rodents in Qena Governorate. M.Sc. Thesis, Faculty of Agricultural Assiut University, 93 pp.

[5]Hussien, S.S.M. (1991): Ecological studies and control of certain rodents in Beni suef Governorate. M.Sc. Thesis, Faculty of Agricultural Cairo University, 176 pp.

[6]El-Deeb, H.I. and Lokma, H.E. (1992): Field studies on population dynamics and reproductive biology of the Nile rat Arvicanthis niloticus. Zagazig Journal of Agricultural Research, 19(3): 1431-1435. [7]Embarak, M.Z. (1997): Ecological and control studies on rodent and their ectorperasits in cultivated and newly reclaimed areas. M.Sc Thesis, Faculty of Agricultural Assiut University, $165 \mathrm{pp}$.

[8]Azzam, K.M.; El-Abd, N.M. and Abd El-Hady, E.A. (2016): Survey of endoparasites of different rodent species in Egypt. Egyptian Journal of Biological Pest Control, 26(4): 815-820.

[9]Rizk, A.M.; Eisa, Y. A.E. and Abdel-Azeem, M.I. (2017): Survey of rodent species at three habitats and control it by use change base carrier of Zinc Phosphide bait technique in Sohag Governorate. Egyptian Academic Journal of Biological Sciences, B. Zoology, 9(1): 33-42.

[10]Claveria F.G.; Jeffrey C.; De Guzman M.A.; Toledo, M. and Salibay, C. (2005): Parasite biodiversity in Rattus spp. caught in wet markets. Southeast Asian Journal of Tropical Medal Public Health, 36(4): 146-148

[11]Waugh, C.A.; Lindo, J.F.; Foronda, P.; Santana, M.A.; Morales, J.L. and Robinson, R.D. (2005): Population distribution and zoonotic potential of gastrointestinal helminths of wild rats Rattus rattus and $R$. norvegicus from Jamaica. Journal of Parasitology, 92(5):1014-1018.

[12]Singleton, G.R.; Smythe, L.; Smith, G.; Spratt, D.M.; Alpin, K. and Smith, A.L. (2003): Rodent diseases in Southeast Asia and Australia :inventory of recent surveys. In: Rats, Mice and people: rodent biology and management. ACIAR Monograph. (Ed: G.R. Singleton, L.A. Hinds, C.J .Krebs and D.M. Sparrt). Canberra, Australian Center for international Agricultural Research, 96: 24-29.

[13]Sumangali, K.; Rajapakse, R.P. V.J. and Rajakaruna, R.S. (2012):

Urban rodents as potential reservoirs of zoonoses: a parasitic survey in two selected areas in Kandy district. Ceylon Journal of Sciences Biological Sciences, 41(1): 71-77.

[14]Coomansingh, C.; Pinckney, R.D.; Bhaiyat, M.I.; Chikweto, S.; Bitner, A.; Baffa, A. and Sharma, R. (2009): Prevalence of endoparasites in wild rats in Grenada. West Indian Veterinary Journal, 9(1): 17-21.

[15]Soliman, S.; Marzouk, A.S.; Main, A.J. and Montasser, A.A. (2001): Effect of six, size, and age of commensal rat hosts on the infestation parameters of their ectoparasites in a rural area of Egypt. Journal Parasitology, 87(6): 1308-1316

[16]El-Kady, G.A.; El-Shazly, A.M., Mikhail, M.W. and Bahgat, I.M. (2007): Ectoparasites of commensal rodents in Talkha Center, Dakahlia Governorate, Egypt. Journal of the Egyptian Society of Parasitology, 37(3): 825-33.

[17]Mahmoud, K.A.; Metwally, A.M.; Mangoud, A.A.H. and Mohamed, A.S. (2008): Survey of commensal rodents and their fleas in different Egyptian Agro-ecosystems. Journal of Agricultural Research, 6: 2105-2116

[18]Desoky, A.S.S. (2011): Studies on certain ectoparasites associated with some farm animals and their control. Ph.D. Thesis, Faculty of Agricultural Assiut, University, 179 pp.

[19]Bahgat, I.M. (2013): Monthly abundance of rodent and their ectoparasites in newly settled areas East of Lakes, Ismailia Governorate Egypt. Journal of the Egyptian Parasitology, 43(2): 387398.

[20]Karg, W. (1971): Acari (Acarina), Miben, Unterordung Analinochaeta (Parasitiformes). Die freilebendeen Gamasina (Gamasides). Jena Teil, 59: 475pp.

[21]Hughes, A.M. (1961): The mites of stored food. Ministry of Agriculture, Fisheries and Food Technical Bulletin, 9: 1-379.

[22]Hughes, A.M. (1976): The mites of stored food and houses. Ministry of Agriculture, Fisheries and Food Technical Bulletin, 9: 1287.

[23]Krantz, G.M. (1978): A manual of Acarology $2^{\text {nd }}$ end. Oregon State University, Corvallis, Oregon, 509 pp

[24]Evans, G.O. (1992): Principles of Acarology. C.A.B. International Walling Ford, 522 pp.

[25]Zawen, V. (2019): Home remedies for lice: Effectiveness and prevention.

//www.medicalnewstoday.com/articles/325844home-remedies.

[26]Regino, C.; Andrade, A.; Muschetto, E. and Cueto, G. (2008): Hair structure of small rodents from central Argentina: A tool for species identification. Mammalia, 72: 35-43. 